\title{
JOINT SLOVAK-UKRAINE-GERMANY BEECH ECOSYSTEMS AS THE WORLD NATURAL HERITAGE
}

\author{
IVAN VOLOŠČUK
}

Matej Bel University, Faculty of Natural Sciences, Institute for Landscape and Region Research, Cesta na amfiteáter 1, 97400 Banská Bystrica, Slovak Republic; e-mail: ivoloscuk@azet.sk

\begin{abstract}
Vološčuk I.: Joint Slovak-Ukraine-Germany beech ecosystems as the World Natural Heritage. Ekológia (Bratislava), Vol. 33, No. 3, p. 286-300, 2014.

The European beech Fagus sylvatica L. ssp. sylvatica L. is exclusively found in Europe. The beech survived the ice age in small refuges in the south and south-east Europe and went on to colonise large parts of the continent. The post-ice age colonisation of the landscape by the beech took place parallel to the settlement of land by humans and the formation of a more complex society. For centuries much of the Carpathian mountain forests remained untouched (Fig. 1). Virgin forests constitute a natural heritage of global significance. In 2007, 10 protected areas with the Primeval Beech Forests of Carpathians (Slovakia, Ukraine) were added to UNESCO's World Heritage List. On 25 June 2011, the UNESCO World Heritage Committee added five of Germany's beech forest protected areas to the World Heritage List. This extended the transboundary world natural heritage site 'Primeval Beech Forest of the Carpathians', located in the Slovak Republic and Ukraine, to include a German forest protected areas, and renamed it 'Primeval Beech Forests of the Carpathians and Ancient Beech Forests of Germany'. This paper is aimed at the presentation of the outstanding universal value of the ecological processes in the Joint World Heritage Sites, short description of protected areas and principles of their integrated management plan. This paper also deals with problems in management plan realisation in practice. Ultimate goal is to achieve that management and socio-economic sustainable development practices are in harmony with primary objectives of World Heritage Site protection, biodiversity conservation, ecosystem and landscape stability, rational use of natural resources, ecotourism development and with potential of the landscape in largest possible extend.
\end{abstract}

Key words: primeval beech forest, ancient beech forest, World Natural Heritage, integrated management plan.

\section{Introduction}

The phenomenon of forests dominated by a single tree species as vegetation over a major part of entire continent is unique to Europe (Knapp, 2011). Thanks to its extremely high ecological competitiveness, the Fagus sylvatica spread to cover wide areas throughout Europe over the course of postglacial forest development and took over an extremely wide ecological spectrum of sites (Akeroyd, 1993; Le Goff, 1990; Manos, Stanford, 2001; Magri et al., 2006).

Europe's beech forests are deciduous forests which are dominated by the European beech (F. sylvatica L.; Barna et al., 2011). The beech is endemic to Europe and beech forests are 


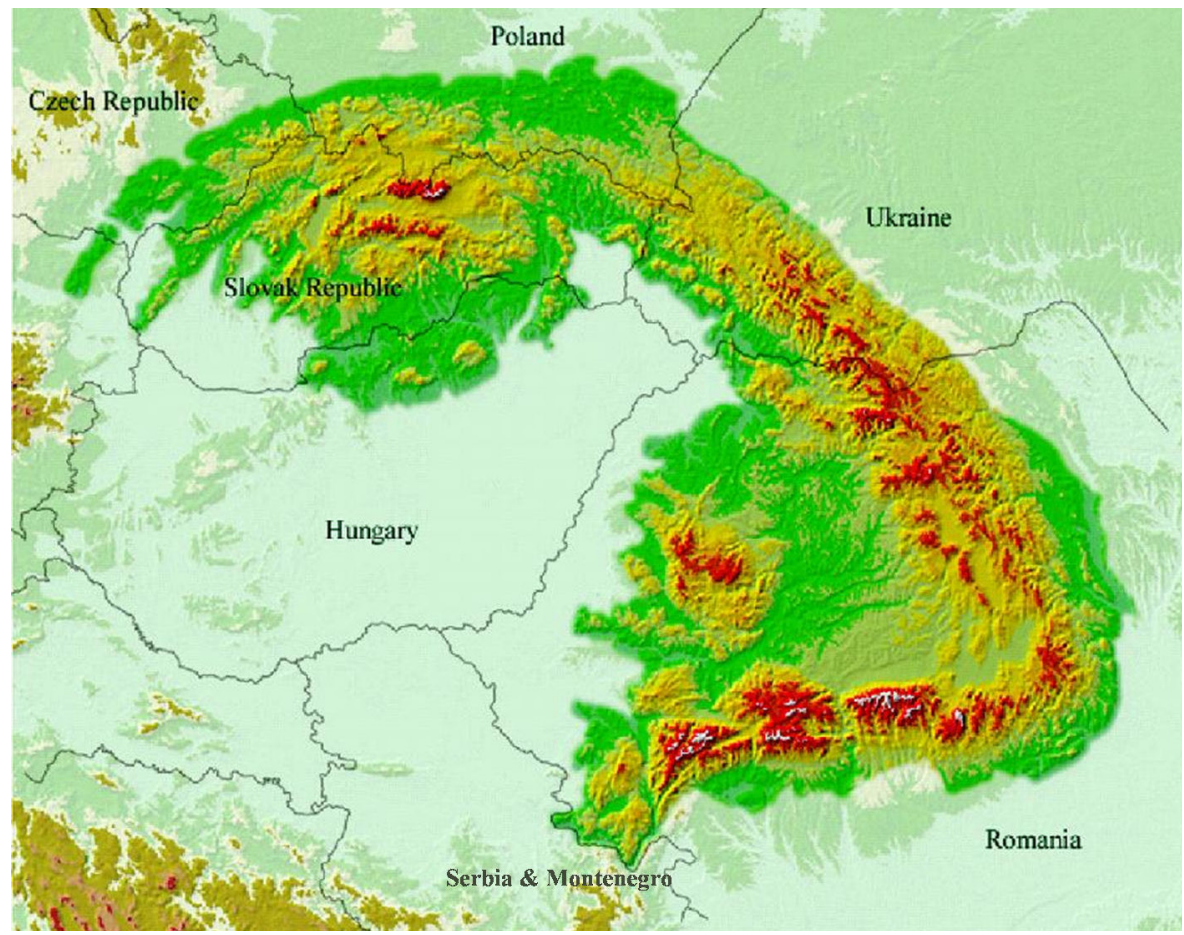

Fig. 1. The Carpathian belt in Central Europe.

limited to Europe (Gömöry et al., 2011). Such forests therefore share the fate of all deciduous forests of the northern hemisphere's nemoral zone (Bohn, Neuhäusl, 2003). They have been exposed to an enormous development pressure (settlement, utilisation) for centuries, so that natural forests have become scarce (Britz et al., 2009; Kozak et al., 2007). Beech is one of the most important elements of forests in the temperate broadleaf forest biome (Udvardy, 1975) and represents an outstanding example of the re-colonisation and development of terrestrial ecosystems and communities after the ice age, a process which is still ongoing (Knapp, 2011). Forest communities built up and dominated by the beech are widespread across major parts of Central Europe (Brädli, Dowhanytch, 2003; Hamor, Commarmot, 2005). The model of the main natural successional phases occurring in Central Europe contains: grow-up stage, optimal stage, decaying stage (Drössler, 2006; Drössler, Lupke, 2005; Koop, Hilgen, 1987; Korpel', 1982, 1989, 1995; Leibundgut, 1978, 1982, 1993; Meyer, 1999; Oheimb et al., 2005; Saniga, 2011; Saniga, Schütz, 2001; Zukrigl et al., 1963).

In the grow-up stage, trees are found in all three layers - upper, middle and lower - and the crown closure is dense. As there is low mortality of trees in this age, there is little dead wood (Korpel', 1995; Saniga, Schütz, 2002). In the end phases, however, the competition between individuals is so great and high mortality of juveniles occurs. In the following optimal stage, the maximum timber stock is reached, but the number of trees per unit area is low. With the lack of an understory (Mölder et al., 2008, Saniga, 2002, 2003), the attainment of 
maximum height and a closed canopy, the forest in this phase is known as 'hall-forest', being reminiscent of the interior of a cathedral or great hall, and also bears some resemblance to a commercial forest. During the transition to the decaying stage, tree vitality decreases and the proportion of dead wood increases considerably. In this phase, the number and size of gaps between tree clusters increases and regeneration of climax tree species starts again.

A significant feature of the beech forests is decline in floristic diversity (Barbier et al., 2008; Falkengren-Grerup, Tyler, 1991), which is a result of the history of flora and vegetation, from the former glacial refuges in southern and southeastern Europe up the northern and northwestern subterritories (Mölder et al., 2008). Old beech trees can form a highly diverse habitat for fauna (Brang, 2005). The beech is a key species that creates its own internal forest climate and crucially influences soil formation, regeneration cycle, food chains and structures reveals an astonishingly specific diversity of plants, vertebrates, insects, molluscs and fungi (Diershke, Bohn, 2004; Dörfelt, 2008). This diversity is described in terms of its ecological role in the ecological processes of beech forest ecosystems - trees and scrubs, mycorrhizae, geophytes, other herbaceous plants, lianas, herbivores, carnivores, dead wood inhabitants, destruens, etc. (Assmann et al., 2008; Capotorti et al., 2010).

The ecological process is understand as a continuous action or series of action that is governed or strongly influenced by one or more ecosystems (a system of plants, animals and other organisms together with the non-living components of their environment). Natural ecosystem is understand as an ecosystem where since the industrial revolution (say 1750) human impact (1) has been no greater than that of any other native species, and (2) has not affected the ecosystem's structure. Human impact excludes changes of global extent, such as climate change due to global warming (IUCN/UNEP/WWF, 1991). Valuable knowledge concerning ongoing ecological processes in the Carpathian primeval beech forest ecosystems and the ancient beech forests of Germany has been obtained during the past 75 years and utilised for practical forest and conservation management.

The Primeval Beech Forests of the Carpathians (Slovakia and Ukraine) have been inscribed on the World Heritage List on 28 June 2007 under criteria of outstanding universal value (ix) (Pichler et al., 2007a; Plachter et al., 2008).

The Decision of the 35. Session of the World Heritage Committee, Paris 25 June 2011, approved the extension of the Primeval Beech Forests of the Carpathians (Slovakia and Ukraine), to include the Ancient Beech Forests of Germany, and becomes the Primeval Beech Forests of the Carpathians and the Ancient Beech Forests of Germany (Slovakia, Ukraine and Germany), on the basis of criterion (ix): outstanding examples representing significant ongoing ecological and biological processes in the evolution and development of ecosystems and communities of plants and animals (Britz et al., 2009). The German extension in 2011 is another major step toward transboundary protecting this unique ecosystem for the long term (Turnock, 2002). The formal approval of beech forests in the territory of the Slovak and Ukrainian Carpathians and ancient beech forests of Germany as part of the World Heritage is in line with the UNESCO guidelines and points to the special global importance and integrity of nature reserves which form the skeleton of listed sites.

These forests and adjacent grasslands with the original tree species composition are important model territories enabling research and application of knowledge about the natural 
development processes in undisturbed beech ecosystems. They are unique in the global context and their protection can be provided only in the presence of conservation initiatives and interested local authorities and institutions responsible for their management.

\section{Characteristics of protected areas as the World Natural Heritage}

The World Heritage Sites with beech ecosystems in Europe comprising 15 components: 10 in Slovak - Ukrainian Carpathians and 5 in Germany. From IUCN categorisation point of view (Bishop et al., 2004; Dudley, Phillips, 2006; EUROPARK, IUCN, 2000; IUCN, 1994; Hockings et al., 2006, Lockwood et al., 2006; Phillips, 2002; Thomas, Middleton, 2003) the World Heritage Sites in Slovakia are situated in strict protected nature reserves (IUCN Category I) of Poloniny National Park (Fig. 2; IUCN Category II) and in nature reserves of Vihorlat Protected Landscape Area (IUCN Category V) (Vološčuk, 1999). The World Heritage Sites in Ukraine are situated in territory of Carpathian Biosphere Reserve (Fig. 3; this is the strict protected category in Ukraine, by IUCN Category I) (Hamor, Commarmot, 2005) and in nature reserves of Uzhansky National Nature Park (IUCN Category II) (Kricsfalusy et al., 2001). In Germany the World Natural Heritage Sites are situated in national parks (IUCN Category II) (Britz et al., 2009).

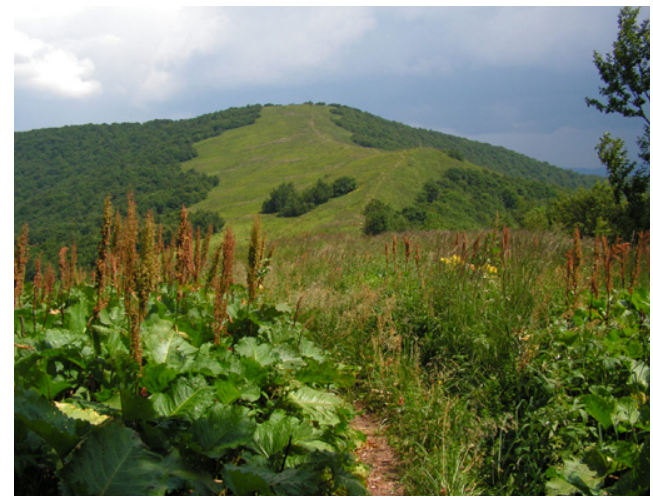

Fig. 2. Mountain meadows ('Poloniny') in Poloniny National Park, Slovakia (Photo by I. Vološčuk).

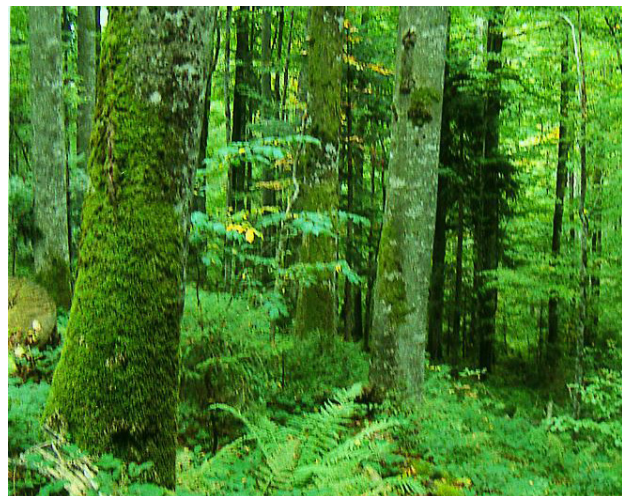

Fig. 3. Primeval beech forest in Carpathian Biosphere Reserve, Ukraine (Photo by I. Vološčuk).

The geographical coordinates of the Primeval Beech Forests of the Carpathians (centre of protected areas) are shown in Table 1.

- Havešová, Slovakia, 171 ha. Havešová National Nature Reserve in Poloniny National Park contains nearly homogenous, largely monodominant mature beech forests and the tallest and largest European beech specimens in the world. Flysch sandstone, 500-700 m a.s.l.

- Rožok, Slovakia, 67 ha. Rožok National Nature Reserve within the buffer zone of Poloniny National Park, contains nearly homogenous, largely monodominant mature beech forests. The northern thorough western flysch sandstone hillsides of the Bukovské Mts, 500-790 m a.s.l., are home of primeval beech forests of all developmental 
T a b le 1. Geographical coordinates of the Primeval Beech Forests of the Carpathians.

\begin{tabular}{|l|l|l|c|c|c|}
\hline $\begin{array}{l}\text { Site element } \\
\text { No. }\end{array}$ & Name & $\begin{array}{l}\text { Coordinates of } \\
\text { centre point }\end{array}$ & $\begin{array}{l}\text { Area of core } \\
\text { zone (ha) }\end{array}$ & $\begin{array}{l}\text { Area of buffer } \\
\text { zone (ha) }\end{array}$ & Country \\
\hline 1 & $\begin{array}{l}49^{\circ} 00^{\prime} 35^{\prime \prime} \mathrm{N} \\
22^{\circ} 20^{\prime} 20^{\prime \prime} \mathrm{E}\end{array}$ & 171.3 & 64.0 & Slovakia \\
\hline 2 & $\begin{array}{l}\text { Stužica, Poloniny National } \\
\text { Park-Zone A }\end{array}$ & $\begin{array}{l}49^{\circ} 05^{\prime} 10^{\prime \prime} \mathrm{N} \\
22^{\circ} 32^{\prime} 10^{\prime \prime} \mathrm{E}\end{array}$ & 2950.0 & $11,300.0$ & Slovakia \\
\hline 3 & $\begin{array}{l}\text { Rožok State Nature } \\
\text { Reserve }\end{array}$ & $\begin{array}{l}48^{\circ} 58^{\prime} 30^{\prime \prime} \mathrm{N} \\
22^{\circ} 28^{\prime} 00^{\prime \prime} \mathrm{E}\end{array}$ & 67.1 & 41.4 & Slovakia \\
\hline 4 & $\begin{array}{l}\text { Vihorlat Protected } \\
\text { Landscape Area }\end{array}$ & $\begin{array}{l}48^{\circ} 18^{\prime} 22^{\prime \prime} \mathrm{N} \\
22^{\circ} 11^{\prime} 23^{\prime \prime} \mathrm{E}\end{array}$ & 2578.0 & 2413.0 & Slovakia \\
\hline 5 & $\begin{array}{l}\text { Uholka-Shyrokyi Luh } \\
\text { Biosphere Reserve }\end{array}$ & $\begin{array}{l}48^{\circ} 55^{\prime} 45^{\prime \prime} \mathrm{N} \\
23^{\circ} 41^{\prime} 46^{\prime \prime} \mathrm{E}\end{array}$ & $11,860.0$ & 3301.0 & Ukraine \\
\hline 6 & $\begin{array}{l}\text { Chornohora Biosphere } \\
\text { Reserve }\end{array}$ & $\begin{array}{l}48^{\circ} 08^{\prime} 25^{\prime \prime} \mathrm{N} \\
24^{\circ} 23^{\prime} 35^{\prime \prime} \mathrm{E}\end{array}$ & 2476.8 & $12,925.0$ & Ukraine \\
\hline 7 & $\begin{array}{l}47^{\circ} 56^{\prime} 21^{\prime \prime} \mathrm{N} \\
24^{\circ} 08^{\prime} 26^{\prime \prime} \mathrm{E}\end{array}$ & 1369.6 & 3163.4 & Ukraine \\
\hline 8 & Biosphere Reserve & $\begin{array}{l}47^{\circ} 56^{\prime} 12^{\prime \prime} \mathrm{N} \\
24^{\circ} 19^{\prime} 35^{\prime \prime} \mathrm{E}\end{array}$ & 2243.6 & 6230.4 & Ukraine \\
\hline 9 & $\begin{array}{l}\text { Maramorosh Biosphere } \\
\text { Reserve }\end{array}$ & $\begin{array}{l}49^{\circ} 04^{\prime} 14^{\prime \prime} \mathrm{N} \\
22^{\circ} 03^{\prime} 01^{\prime \prime} \mathrm{E}\end{array}$ & 2532.0 & 3615.0 & Ukraine \\
\hline 10 & $\begin{array}{l}48^{\circ} 11^{\prime} 21^{\prime \prime} \mathrm{N} \\
24^{\circ} 13^{\prime} 37^{\prime \prime} \mathrm{E}\end{array}$ & 3030.5 & 5639.5 & Ukraine \\
\hline Park & $\begin{array}{l}\text { Svydovets Biosphere } \\
\text { Reserve }\end{array}$ & & $29,278.9$ & $48,692.7$ & \\
\hline
\end{tabular}

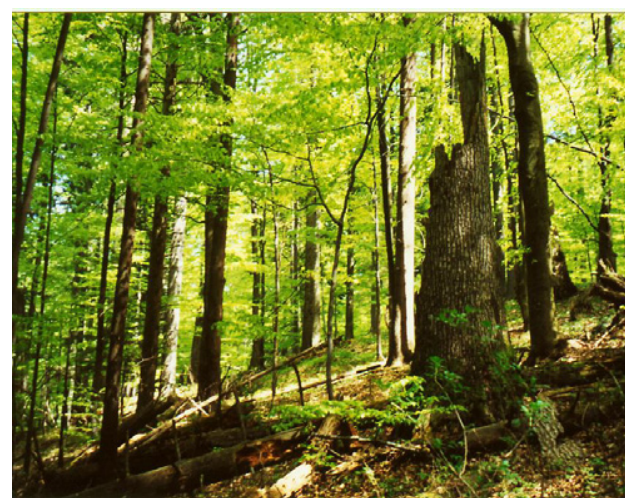

Fig. 4. Primeval beech forest in Stužica National Nature Reserve, Poloniny National Park. stages. East Carpathian flora and the nesting grounds of owls and storks are found in the area.

- Stužica-Bukovské Vrchy, Slovakia, 2950 ha. A continuous complex of primeval beech forests comprising Stužica National Nature Reserve and parts of the core zone of Poloniny National Park, extending along the Slovakian, Ukrainian and Polish borders. Flysch sandstones and clay shales. 650-1221 $\mathrm{m}$ a.s.l. Huge beeches, mountain maples, firs and mountain meadows (Poloniny) along with East Carpathian species of flora and fauna. Up to 560 trees occupy a single hectare here (Fig. 4).

- Vihorlat, Slovakia, 2578 ha. Vihorlat National Nature Reserve, Morské oko National Nature Reserve and planned core area with continuous beech woods complex of primeval beech forests in the Vihorlat Protected Landscape Area. A typical strato-volcano composed mainly of andesites with the andosols and occurrence of warm-climate and important mountainous plant species. 600-1075 m a.s.l. Plant and animal habitats typical for Eastern Slovakia.

- Chornohora, Ukraine, 2476 ha. Diverse beech forest communities in the Carpathian Biosphere Reserve and representative of natural beech forests originally looked like in 
much of Central Europe. Flysch sandstones and clay shales. 600-1250 m a.s.l.

- Kuziy-Trybushany, Ukraine, 1369 ha. Oak-beech-fir forests in the Carpathian Biosphere Reserve and remarkable because of their diverse forest communities and 35 Red Data Book species. Gneiss, quartzite, dolomites, limestone and hard marlstone. 360-800 $\mathrm{m}$ a.s.l.

- Maramorosh, Ukraine, 2243 ha. Mostly mixed beech-spruce and beech-fir forests in the Carpathian Biosphere Reserve and near the Romanian Maramures National Park. Crystalline massif and flysch carbon-terigen sediments, volcanic rocks, carbonate rocks, metamorphic rocks. $380-1300 \mathrm{~m}$ a.s.l.

- Stuzhytsia-Uzhok, Ukraine, 2532 ha. A part of the Uzhanskyi Nature National Park containing mature beech forests, extending along the Ukrainian, Slovakian and Polish borders, and connecting directly to Stužica-Bukovské Vrchy. Flysch sandstones, cambisols. $400-1250 \mathrm{~m}$ a.s.l.

- Svydovets, Ukraine, 3030 ha. Diverse beech forest communities in the Carpathian Biosphere Reserve and the richest flora in the Ukrainian Carpathians. Flysch formations with dominating claystones and aleurites, sandstones with admixture of limestone. 350 $1250 \mathrm{~m}$ a.s.l.

- Uholka-Shyrokyi Luh, Ukraine, 11860 ha. Different forest communities across the range of environmental conditions, with beech trees up to $50 \mathrm{~m}$ in height and $130 \mathrm{~cm}$ in diameter and with a number of endemic and relict species, form this so called phytocoenotic core of the Carpathian Biosphere Reserve. It is the largest primeval beech forest of the world. Sandy - clayed flysch with element of karst landscape (limestone rocks). 380-1300 m a.s.l. (Fig. 5).

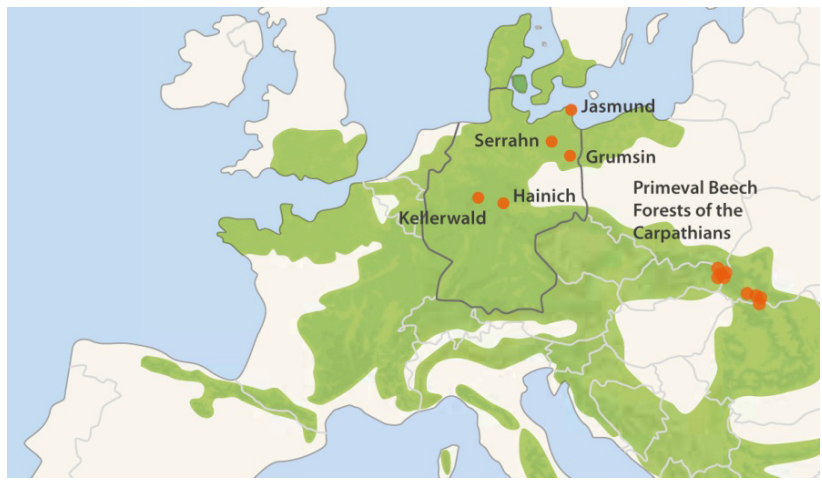

Fig. 5. Situation of Primeval Beech Forests of the Carpathians and Ancient Beech Forests of Germany (Author M. Grossmann).

- German's component parts are the most outstanding examples worldwide of the respective beech forest types. Each component part has its own specific characteristics and local peculiarities that make it unique and irreplaceable.

- Jasmund, Mecklenburg-West Pomerania. Jasmund National Park. 493 ha, buffer zone 2510.5 ha. $54^{\circ} 32^{\prime} 53^{\prime \prime} \mathrm{N}, 13^{\circ} 38^{\prime} 43^{\prime \prime} \mathrm{E}, 0-131 \mathrm{~m}$ a.s.l. Jasmund is representative of the beech forest of the lowlands type. Half of Jasmund's property border follows to coast- 


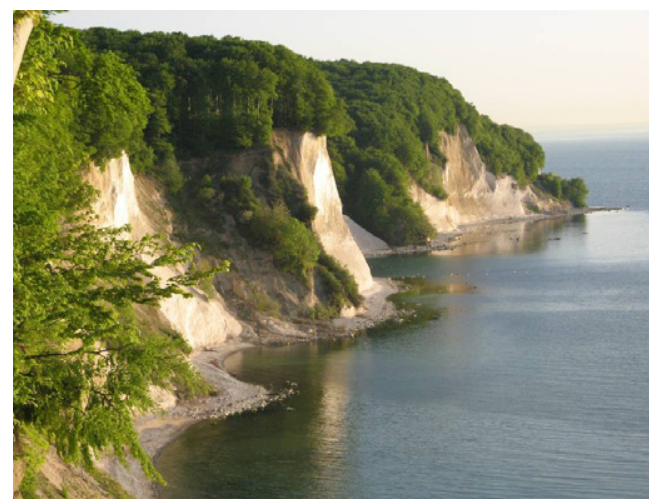

Fig. 6. Ancient beech forests in Jasmund National Park, Germany (Author M.Grossmann).

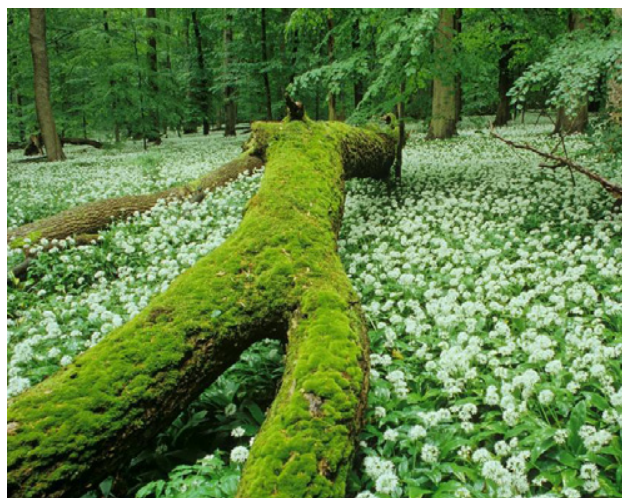

Fig. 7. Ancient beech forest in Heinich National Park, Germany (Author M. Grossmann).

line. Although this border is subject to very slow natural dynamic changes based on the denudation of the steep coast, it is clearly identifiable by distinctive habitat limits at any given point. Jasmund represents the beech forests of the lowlands on lime and boulder clay. Beech forests, chalk cliffs and sea form a fascinating backdrop. The harsh coastal climate and the interaction of topography and climate lead to a broad range of different beech forest communities which are interspersed with streams and moors. Rare orchids, the great horsetail and the coral root are typical here (Fig. 6).

- Serrahn, Mecklenburg-West Pomerania. Müritz National Park. 268 ha, buffer zone 2568.0 ha. $53^{\circ} 20^{\prime} 24^{\prime \prime} \mathrm{N}, 13^{\circ} 11^{\prime} 52^{\prime \prime} \mathrm{E}, 67-124 \mathrm{~m}$ a.s.l. The best structured lowland beech forests in Europe. Demarcation in Serrahn has produced a compact core area of beechdominated forests. In the Serrahn part the forest of the Müritz National Park lowland beech forests grow on sands from the Ice Age. In the midst of an extended forest and lake landscape this old beech forests helps us to imagine what the German beech forests once looked like. Lakes and mires enrich the forest landscape, create a rich diversity of habitats and form the basis for a great amount of biodiversity. The beech forest of Serrahn consequently documenting moisture-related distribution limits in an outstanding manner.

- Grumsin, Brandenburg. 590 ha, buffer zone 274.3 ha. 52 $59^{\circ} 11^{\prime \prime}$ N, 1353'44" E, 76-139 $\mathrm{m}$ a.s.l. Grumsin represents the beech forests of the lowlands on glacial sands and clay. The demarcation of the Grumsin component part largely follows the core area border of the Schorfheide-Chorin Biosphere Reserve, which was designated in 1990. Minor marginal zones which predominantly consist of pine woods rather than near-natural deciduous forests and were likewise abandoned to natural development in 1990 have been assigned to the buffer zone. Water and forests are closely linked in Grumsin. Lakes, forest marches and moores in deep valleys interchange with marked ridges and conjure up atmospheric forest images in the ancient beech forests. These different structures in the most confined spaces form the basis for an exceptionally rich range of animal and plant species. The area represents an exceedingly textured young moraine landscapes with altitudes of between 60 and $140 \mathrm{~m}$ a.s.l. and all the typical elements in a unique fashion. 
- Hainich, Thuringia. Hainich National Park. 1573 ha, buffer zone 4085.4 ha. $51^{\circ} 04^{\prime} 43^{\prime \prime} \mathrm{N}$, $10^{\circ} 26^{\prime} 08^{\prime \prime}$ E, 290-490 m a.s.l. Hainich National Park encompasses what is, at present, the largest unmanaged deciduous forest area in Germany. Hainich represents the best reference area for the specious eutraphentic beech forests of the European colline-submontane zones with their ground vegetation rich in geophytes and the exceedingly attractive floral display in early spring, representing the seasonality of Central European deciduous forests in a unique manner. The most valuable beech forests that offer a very rich range of species grow on the central mountain ranges on limestone. It impresses through its extensive range of tree species and reveals lime beech forests of a magnitude, unspoilt nature and form that you will be unable to find in any other area. The demarcation in Hainich follows the distribution of the best-preserved beech forests with old growth stands. The buffer zone comprises the core area of the national park. The Hainich beech forest is unique proof of the currently ongoing ecological processes associated with the present climate change (Fig. 7).

- $\quad$ Kellerwald, Hesse. Kellerwald - Edersee National Park. 1467 ha, buffer zone 4271.4 ha. $51^{\circ} 08^{\prime} 43^{\prime \prime} \mathrm{N}, 08^{\circ} 58^{\prime} 25^{\prime \prime} \mathrm{E}, 245-626 \mathrm{~m}$ a.s.l. The acidophilus beech forests of the lower mountain ranges grow on slate and greywacke in the Kellerwald. No roads and no settlement cut through the exceptionally old, extensive forests of the Kellerwald in which unique primeval forest relics have survived. The beech reaches its natural forest boundary at the rocky and scree slopes and forms a bizarrely formed forest landscape. More of than 500 of the purest springs and streams form additional valuable habitats. In Kellerwald, the border was established taking into account the specific qualities of the component part, such as the high relief energy, the disjointed occurrence of small primeval-forest like steep slopes, and the spatial distribution of valuable beech forests. A coherent complex of valuable old-growth beech forests has been included. The demarcation of buffer zone follows the national park border. No buffer has been designated in a very small plot located on the northern border in order to integrate one of the primeval beech forest slopes into the property. Kellerwald contains the largest protected area of oligotraphent and mesotraphent beech forests, where undisturbed ecological and biological processes occur and is a perfect illustration of acidophilus beech forests.

\section{Implementation of integrated management plan for the World Heritage Properties}

Long-term protection and management of the protected areas and especially of the World Heritage Sites is ensured through national legal protection as national parks, protected landscape areas and nature reserves (Cooney, 2004; IUCN WCPA, 2000; Kuemmerle et al., 2008; Levrel, 2007; Lockwood et al., 2006; Stolton, Dudley, 1999; Synge, 2004; Thomas, Middleton, 2003; Wilshusen et al., 2002; Zbicz, Green, 1997).

Long-term research of the Carpathian primeval beech forests (Brändli, Dowhanytsch, 2003; Bublinec, Pichler, 2001; Commarmot et al., 2000; Giurgiu et al., 2001; Hamor, Commarmot, 2005; Jaworski et al., 1994a, b; Korpel', 1995; Pichler et al., 2007a, b; Saniga, 2002, 2003, 2011; Saniga, Klimaš, 2004; Saniga, Schütz, 2001, 2002; Saniga, Sklenár, 2003; Stoyko, 2002; Stoyko, Tasekevitch, 1993; Stoyko et al., 1982; Vološčuk, 1992, 1994, 1995, 2003; Zlatník, 1934, 1935, 1936; Zlatník et al., 1938) and of the ancient beech forests of Germany (Britz et al., 2009) results 
in practical guidance for developing and managing of beech forests in nature reserves, national parks and landscape protected areas.

The general objectives of the integrated management plan for the World Heritage Sites are (Pichler et al., 2007a,b):

- To ensure the most effective conservation of the WHS properties with all their abiotic and biotic components, geo- and biodiversity and ecological processes. To secure a lasting homeostasis and self-reproduction of the respective ecosystems and their protection both against anthropogenic factors (Čeřovský, 1996; Denisiuk, Stoyko, 2000; Hamilton, McMillan, 2004; Hamilton et al., 1996; Phillips, 2000; Stolton et al., 2012; Synge, 2004).

- To maintain and expand the existing, ecologically connected complex of primeval and natural beech forests that encompass the WHS within the corridors connecting the WHS. Supporting the succession of managed beech seminatural forests (Bennett, 1994, 1998; Bishop et al., 2004; Sandwith et al., 2001; Stolton et al., 2003, Pichler et al. 2007b).

- To use WHS for scientific research in order acquire knowledge transferable and applicable on the level of sustainable (Otto, 1994; Vološčuk, 1992, 1994, 1995, 2003). To use WHS for enhancement of landscape ecological stability (Peterson et al., 1998).

- To use WHS for enhancement of ecological and environmental education, awareness of primeval forests - chosen to maintain integrity and conservation of the existing sites, to preserve their naturalness and uniqueness (Stolton, Dudley, 1999; Turnock, 2002).

- To support of traditional crafts, products and ecotourism (Balandina et al., 2012; CeballosLascuráin, 1996; Eagles et al., 2002; EUROPARK Federation, 1993; Gebhard et al., 2007; Pichler, Soroková, 2005).

Common elements of an effective management system could include: (a) a thorough shared understanding of the property by all stakeholders; (b) a cycle of planning, implementation, monitoring, evaluation and feedback (Hocking et al., 2000, 2006; IUCN WCPA, 2000); (c) the involvement of partners and stakeholders (EUROPARK Federation, 1993; Synge, 2004); (d) the allocation of necessary resources; (e) capacity-building and (f) an accountable, transparent description of how the management system functions (Levrel, 2007).

\section{Discussion}

Implementation of mentioned management theory in practice is different in Germany, Ukraine and Slovakia. The main problem is the private ownership in national parks and nature reserves. Slovakia, Ukraine and Germany are post-communist counties and since 1990 the ownership was changed.

In Germany permanent protection of the World Heritage Property (National Park Jasmund, National Park Serrah, Grumsin - Biosphere Reserve Schorfheide - Chorin, National Park Hainich, National Park Kellerwald) is ensured by the ownership structure. The property of national parks is almost entirely publicly owned. The owners are Länder and municipalities. In the Schorfheide-Chorin Biosphere Reserve (Grumsin) the domain are in private ownership for the most part (81\%), with $64 \%$ being owned by the non-profit organisation. The area of 375 ha was purchased by means of public funds and the allocation of which is associated with the pertinent obligations, most notably the non-intervention policy. In German, five properies, 
only a small portion of $3.3 \%$ of all component parts is privately owned with a purpose solely governed by private law. This area will be purchased in the foreseeable future by the territorial communities by way of acquisition or relocation (Britz et al., 2009). Functional protection within the five component parts and their buffer zones is ensured by designation of protected areas by low or ordinances, administrative bodies responsible for the management of the component parts, and management plans specifically devised for the protected areas including the component parts.

In Ukraine the World Heritage property in the Carpathian Biosphere Zapovednik (Reserve) and Uzhanskyi Nature National Park is state owned. The protection is ensured by designation of this protected area by the Law of Ukraine 'On Nature Protection Fund of Ukraine'. The management of the properties buffer zone is regulated by the state Laws of Ukraine. The connecting corridors linking the properties are subject to the Law of Ukraine 'On establishing of the Ukrainian National Ecological Network' (No. 1989-111). These forests are thus either under state protection and designated already for the future extension of the Carpathian Biosphere Zapovednik (Reserve) or they are reserved for the establishment of new protected areas. In Ukraine there are no problems with management plan realisation.

In Slovakia problem with the management plan realisation in practice is complicated because of ownership structure. The owners of the World Heritage Property in Poloniny National Park and Vihorlat Protected Landscape Area are state (40\%) and small non-state company -'urbariát' (60\%). The Poloniny National Park and Vihorlat Protected Landscape Area have been established in former totalitarian political system without the approval of 'urbariát' company. After 1990 the land use was returned to primary ownerships (urbariáts), which require financial compensation for restriction of their ownership right to using the protected forest areas. That refer also to World Heritage Primeval Beech Forests.

Protection measures related to the mentioned beech primeval forests on the Slovak territory are regulated by the provisions of Act of the Slovak National Council No. 543/2002 Coll. on Nature and Landscape Protection (hereinafter only Act). In the wording of $\$ 16$, section 1 of the Act, any interventions are prohibited in Nature Reserves as strictly protected areas. The cited protection regimes correspond to Ia management regime of IUCN classification (on $2113 \mathrm{ha}$ ), but some parts of the Slovak beech forests is potential threatened by human activities. Every nominated property is individually covered by an approved forest management plan (legal norms providing for the forest management plans are contained in the $\$ 2$ and $\$ 40$ of the Act of the Slovak National Council No. 326/2005 Coll. on the forest management and state administration of forest management) for a 10 -year period, but stipulates no-intervention policy only in these existing protected areas.

The management plan adopted by the World Heritage Committee in 2007 has not been implemented in some crucial parts of the Slovak World Heritage due to reason of the six long years negotiations with the stakeholders about necessity to planned expansion of core zone (a difference compared to the nomination of $3564 \mathrm{ha}$ ).

The solution of the Ministry for Environment of the Slovak Republic in 2013 for integrated management of Slovak World Heritage Sites can be summarised in the following manner:

- Uncompromised application of management and conservation of nature forests in existing strict protected nature reserves based on scientific knowledge about primeval beech forests 
with the consensus by all stakeholders; the non-state companies - 'urbariát' are not agree with purchase or relocation of their forests;

- Realisation of new project mapping in existing and potential protected areas, which are located in and outside of World Heritage Sites;

- Continuing monitoring of the property through legal framework of the cross-sectoral cooperation and coordinated with Joint Management Committee, under preparing Joint Declaration of Intent (Slovakia, Ukraine and Germany);

- Implementation of the broad participatory principle through the bottom-up approach aimed at voicing the stakeholders' interests and thereof translation into concrete results benefiting the local population, mostly in terms of ecotourism development, public relations and marketing and their spin-off effects (the establishing of the National steering committee of the property).

Combined top-down and the bottom-up approach to enhance integrity and value of Primeval Beech Forests of Carpathians through the formal establishment of corridors connecting the inscribed properties and their embedding into the regional territorial plans.

The management of the buffer zones (zone B) is regulated by the Act No. 543/2002 Coll. On Nature and Landscape Protection. Only measures in support of natural processes are allowed within a buffer zone. Such measures are planned, if necessary, in the management plans of national nature reserves, and projected into binding forest management plans.

The forests of the connecting corridors are located within the boundaries of the Poloniny National Park and Vihorlat Protected Landscape Area. Thus, they are subject to forest management plans, in which the application of close-to nature continuous-cover forestry toolbox is secured by the obligatory incorporation of 'protected area maintenance programme', worked out by the respective authority (Poloniny NP and Vihorlat PLA) in compliance with Regulation of the Ministry of the Environment of the Slovak Republic, and subject to the approval by the Government of the Slovak Republic.

\section{Conclusion}

Maintaining a joint World Heritage natural beech forests in Slovakia, Ukraine and Germany is a challenge for the participating countries to improve protection principles and sustainable development of natural beech ecosystems. In view of the complicated ownership relations in the Slovak protected areas included in the World Heritage Site, it is necessary that conservation and forestry state administration bodies together interacted with forest owners, stakeholders, local people and reach a compromise in the implementation of integrated management plan for natural forest of Joint World Natural Heritage.

Acknowledgements

This study was supported by the Grant the Agency for Science VEGA No 1/0172/12.

\section{References}

Akeroyd, J.R. (1993). Fagus L. In T.G. Tutin, V.H. Heywood, N.A. Burges, D.H. Valentine \& D.M. Moore (Eds.), Flora Europea. Vol. 1. Cambridge: Cambridge University Press. 
Assmann, T., Drees, C., Schroder, E. \& Ssymank A. (2008). Low species diversity of beech forests - a myth. In H.D. Knapp (Ed.), Beech Forests - a German contribution to the global forest biodiversity. Bonn: Bundesampt für Naturschutz (BfN), Federal Agency for Nature Conservation, Skripten, 233, 25-31.

Balandina, A., Lovén, L., Ostermann, O. \& Partington R. (2012). European Charter Parks - a growing network for sustainable tourism development in Protected Areas. Parks, 18(2), 132-143.

Barbier, S., Gosselin, F. \& Balandier P. (2008). Influence of tree species on understory vegetation diversity and mechanisms involved - A critical review for temperate and boreal forests. For. Ecol. Manag., 254(1), 1-15. DOI: 10.1016/j. foreco.2007.09.038.

Barna, M., Kulfan, J. \& Bublinec E. (Eds.) (2011). Beech and beech ecosystems of Slovakia (in Slovak). Bratislava: VEDA, vydavatel'stvo SAV.

Bennett, A.F. (1998). Linkages in the landscape: The role of corridors and connectivity in wildlife conservation. Gland, Cambridge: IUCN.

Bennett, G. (Ed.) (1994). Conserving Europe's Natural Heritage: Towards a European Ecological Network. London: Graham and Trotman.

Bishop, K., Dudfley, N., Phillips, A. \& Stolton S. (2004). Speaking a Common Language. The uses and performance of the IUCN System of Management Categories for Protected Areas. Cardiff University, IUCN - The World Conservation Union and UNEP - World Conservation Monitoring Centre.

Bohn, U. \& Neuhäusl R. (2003). Karte der natürlichen Vegetation Europas - Masstab 1 : 2500 000. Bonn-Bad Godesberg: Hrsg. Bundesamt für Naturschutz.

Brang, P. (2005). Virgin forests as a knowledge source for central European silviculture: Reality or myth ? For. Snow Landsc. Res., 79(1/2), 19-32.

Brändli, U.B. \& Dowhanytsch Y. (Eds.) (2003). Urvälder im Zentrum Europas. Birmensdorf, Switzerland: Eidgenössische Forschungsanstalt WSL; Rakhiv, Ukraine: Karpaten-Biosphärenreservat. Bern, Stuttgart, Wien, Haupt.

Britz, H., Dieckmann, O., Engels, B., Frede, A., Geisel, T., Grossmann, M., Kaiser, K., Knapp, H.D., Luthardt, M.E. \& Seuring J. (2009). Nomination of the "Ancient Beech Forests of Germany" as Extension to the World Natural heritage "Primeval Beech Forests of the Carpathians". Nationale Naturlandschaften, Federal Republic of Germany. Niedenstein: Specialised editing Cognitio Kommunikation \& Planung.

Bublinec, E. \& Pichler V. (2001). Slovak primeval forests - Diversity and conservation. Zvolen: Ústav ekológie lesa SAV.

Capotorti, G., Del Vico, E., Lattanzi, E., Persiani, A.M., Ravera Blasi, C., Marchetti, M., Chiavetta, U., Aleffi, M., Audisio, P., Azzella, M.M., Brunialti, G., S., Tilia, A. \& Burrascano S. (2010). Multi-taxon and forest structure sampling for identification of indicators and monitoring of old-growth forest. Plant Biosyst., 144(1), 160-170. DOI: $10.1080 / 11263500903560538$.

Ceballos-Lascuráin, H. (1996). Tourism, ecotourism and protected areas: The state of nature based tourism around the world and guidelines forest development. Gland, Switzerland, and Cambridge: IUCN

Commarmot, B., Duelli, P. \& Chumak V. (2000). Urwaldforschung - Beispiel Biosphärenreservat Transcarpatien. Birmensdorf, Switzerland: Naturwerte in Ost und West. Publ. zur Tagung "Forum fuer Wissen", WSL, p. 61-68.

Cooney, R. (2004). The Precautionary Principle in Biodiversity Conservation and Natural Resource Management: An issue paper for policy-makers, researchers and practitioners. Gland, Switzerland and Cambridge: IUCN.

Čeřovský, J. (Ed.) (1996). BiodiversitycConservation in transboundary protected areas in Europe. Praha: ECOPOINT Foundation.

Denisiuk, Z. \& Stoyko S. (2000). The East Carpathians Biosphere Reserve (Poland, Slovakia, Ukraine). In A. Breymayer \& P. Dabrowski (Eds.), Biosphere Reserves on Borders (pp. 79-93). Warsaw: National UNESCO - MAB Committee of Poland.

Dierschke, H. \& Bohn U. (2004). Eutraphente Rotbuchenwälder in Europa. Tuexenia, 24: 19-58.

Dörfelt, H. (2008). Fungi of beech forests. In H.D. Knapp (Ed.), Beech forests - a German contribution to the global forest biodiversity. Bonn: Bundesampt für Naturschutz (BfN), Federal Agency for Nature Conservation. Skripten, 233, 33-36.

Drössler, L. \& Lupke B. (2005). Canopy gaps in two virgin beech forest reserves in Slovakia. J. For. Sci.(Prague), 51, 446-457.

Drössler, L. (2006). Stand structure and gaps of virgin beech forests in Slovakia. In Beech sylviculture in Europe's Largest Beech Country (pp. 18-20). Proceedings of IUFRO Conference, Poliana Brasov, 4. - 8. 9. 2006.

Dudley, N. \& Phillips A. (2006). Forest and protected areas: guidance on the use of the IUCN protected area management categories. Gland, Switzerland and Cambridge: IUCN.

Eagles, P.F.., McCool, S.F. \& Haynes Ch.D. (2002). Sustainable tourism in protected areas: Guidelines for planning and 
management. Gland, Switzerland and Cambridge: IUCN.

EUROPARK Federation (1993). Lowing Them to Death? Sustainable Tourism in Europe's Nature and National Parks. Revised and Republished 2001. Grafenau: EUROPARK Federation.

EUROPARK, IUCN (2000). Guidelines for Protected Area Management Categories - Interpretation and Application of the Protected Area Management Categories in Europe. Grafenau: EUROPARK and WCPA.

Falkengren-Grerup, U. \& Tyler G. (1991). Dynamic floristic changes of Swedish beech forest in relation to soil acidity and stand management. Vegetatio, 95,149-158. DOI: 10.1007/BF00045213.

Gebhard, K., Meyer, M. \& Roth S. (2007). Sustainable tourism management planning in Biosphere Reserve - A methodology guide. Ecological Tourism in Europe, Bonn, Germany and UNESCO MAB.

Giurgiu, V., Donita, N., Bândiu, C., Radu, S., Cenusa, R., Dissescu, R., Stoiculescu, C. \& Iovu A. (2001). Les Forêts Vierges de Roumanie. Asbl. Forêt Wallonne.

Gömöry, D., Kukla, J. \& Schieber B. (2011). Taxonomy, phylogeny and distribution of beech in Europe and in Slovakia (in Slovak). In M. Barna, J. Kulfan \& E. Bublinec (Eds.), Buk a bukové ekosystémy Slovenska (pp. 19-36). Bratislava: VEDA, vydavatel'stvo SAV.

Hamilton, L.S., Mackay, J.C., Worboys, G.L., Jones, R.A. \& Manson G.B. (1996). Transborder protected area cooperation. Canberra: Australian Alps Liaison Committee, IUCN.

Hamilton, L. \& McMillan L. (2004). Guidelines for Planning and Managing Mountain Protected Areas. Gland, Switzerland and Cambridge: IUCN.

Hamor, F. \& Commarmot B. (Eds.) (2003). Natural Forests in the Temperate Zone of Europe - Values and Utilisation. International Conference in Mukachevo, Transcarpathia, Ukraine, October 13 - 17, 2003. Rakhiv, Ukraine: Carpathian Biosphere Reserve, Birmensdorf, Switzerland: Swiss Federal Research Institute WSL.

Hockings, M., Stolton, S. \& Dudley N. (2000). Evaluating Effectiveness: A Framework for Assessing the Management of Protected Areas. Gland, Switzerland and Cambridge: IUCN.

Hockings, M., Stolton, S., Leverington, F., Dudley, N. \& Courrau J. (2006). Evaluating Effectiveness: A Framework for Assessing the Management of Protected Areas. Gland, Switzerland and Cambridge: IUCN.

IUCN/UNEP/WWF (1991). Caring for the Earth. Gland, Switzerland and Cambridge: IUCN.

IUCN (1994). Guidelines for Protected Area Management Categories. CNPPA with the assistance of WCMC. Glang, Switzerland and Cambridge: IUCN.

IUCN WCPA, 2000: Financing Protected Areas. Gland, Switzerland and Cambridge: IUCN.

Jaworski, A., Skrzyszewski, J. \& Pach M. (1994a). Characteristic of Acer pseudoplatanus L. and Fagus sylvatica L. virgin type forests in Bieszczady National Park. In I. Vološčuk (Ed.), Research and Management of the Carpathian Natural and Primeval Forests (pp. 40-49). Ustrzyki Gorne, Poland: Bieszczady National Park, Association of the Carpathian National Parks and Protected Areas.

Jaworski, A., Kaczmarski, J., Skrzysewski, J. \& Swiatkowski W. (1994b). Structure and dynamics of lower subalpine timber stands of Carpathian Mts of primeval character. In I. Vološčuk (Ed.), Research and Management of the Carpathian Natural and Primeval Forests (pp. 23-39). Ustrzyki Gorne, Poland: Bieszczady National Park, Association of the Carpathian National Parks and Protected Areas.

Knapp, H.D. (2011). European beech forests and their biogeographical position. In H.D. Knapp \& A. Fichtner (Eds.), Beech Forests. Joint Natural Heritage of Europe. Bonn: Bundesampt für naturschutz (BfN), Federal Agency for Nature Conservation. Skripten, 297, 9-14.

Koop, H. \& Hilgen, P. (1987). Forest dynamics and regeneration mosaic shift in unexploited beech (Fagus sylvatica) stands at Fontainebleau (France). For. Ecol. Manag., 20, 135-150. DOI: 10.1016/0378-1127(87)90155-1.

Korpel', Š. (1982). Degree of equilibrium and dynamical changes of the forest on example of natural forests of Slovakia. Acta Facultatis Forestalia Zvolen, 24, 9-30.

Korpel', Š. (1989). The primeval forests of Slovakia (in Slovak). Bratislava: VEDA, vydavatel'stvo SAV.

Korpel', Š. (1995). Die Urwälder der Westcarpaten. Stuttgart: Fischer Verlag.

Kozak, J., Estreguil, C. \& Vogt P. (2007). Forest cover changes in the northern Carpathians in the 20th century: A slow transition. European Journal of Forest Research, 126, 77-90. DOI: 10.1007/s10342-006-0160-4.

Kricsfalusy, V., Ivaneha, I., Lugovoj, A., Budnikov, G., Mező-Kricsfalusy, G., Mateleshko, A., Popov, S., Syvokhop, J., Pavlej, J. \& Lesjo I. (2001). Uzhanskyi National Nature Park. Uzhgorod: Karpaty.

Kuemmerle, T., Hostert, P., Radeloff, V.C., van den Linden, S., Perzanowski, K. \& Kruhlov I. (2008). Cross-border comparison of post-Socialist farmland abondonement in the Carpathians. Ecosystems, 11, 614-628. DOI: 10.1007/ s10021-008-9146-z.

Le Goff, J. (Ed.) (1990). Medieval Callings. London: The Chicago University Press. 
Leibundgut, H. (1978). Über die Dynamik europäicher Urwälder. Allgemeine Forstzeitschrift, 24, 686-690.

Leibundgut, H. (1982). Europäische Urwälder der Bergstufe. Bern/Stuttgart: Haupt.

Leibundgut, H. (1993). Europäische Urwälder: Wegweiser zur naturnahen Waldwirtschaft. Bern und Stuttgart: Verlag Haupt.

Levrel, H. (2007). Selecting indicators for the management of biodiversity. Paris: Institut Francais de la Biodiversité.

Lockwood, M., Worboys, G.L. \& Kothari A. (2006). Managing Protected Areas: A Global Guide. London, UK: IUCN and Earthscan.

Magri, D., Vendramin, G.G., Comps, B., Dupanloup, I., Geburek, T., Gömöry, D., Latalowa, M., Litt, T., Paule, L., Roure, J.M., Tantau, I., Van der Knaap, W.O., Petit, R.J. \& de Beaulieu J.L. (2006). A new scenario for the Quaternary history of European beech populations: paleobotanical evidence and genetic consequences. New Phytol., 171, 199-222. DOI: 10.1111/j.1469-8137.2006.01740.x.

Manos, P.S. \& Stanford A.M. (2001). The historical biogeography of Fagaceae: tracking the Tertiary history of temperate and subtropical forests of the northern hemisphere. Int. J. Plant Sci., 162, 77-93. DOI: 10.1086/323280.

Meyer, P. (1999). Determination of development phases and diversity of forest texture. Allgemeine Forst und Jagdzeitung, 170, 203-211.

Mölder, A., Bernhardt-Römermann, M. \& Schmidt W. (2008). Herb-layer diversity in deciduous forests: Raised by tree richness or beaten by beech? For. Ecol. Manag., 256, 272-281. DOI: 10.1016/j.foreco.2008.04.012.

Oheimb, G., Westphal, C., Tempel, H. \& Hardtle W. (2005). Structural pattern of a near-natural beech forest (Fagus sylvatica) (Serrahn, North-east Germany). For. Ecol. Manag., 212, 253-263. DOI: 10.1016/j.foreco.2005.03.033.

Otto, H. (1994). Waldökologie. Stuttgart: Verlag Eugen Ulmer.Peterson, G., Allen, C.R. \& Holling C.S. (1998). Ecological resilience, biodiversity, and scale. Ecosystems, 1, 6-18. DOI: 10.1007/s100219900002.

Phillips, A. (Ed.) (2000). Financing protected areas. Guidelines for protected area managers. Gland, Switzerland: IUCN.

Phillips, A. (2002). Management Guidelines for IUCN Category V Protected Areas, Protected Landscapes/Seascapes. Gland, Switzerland and Cambridge: IUCN.

Pichler, V. \& Soroková M. (2005). Utilisation of natural forests for ecotourism: Matching the goals and reality. For. Snow Landsc. Res., 79(1/2), 185-194.

Pichler, V., Hamor, F., Vološčuk, I. \& Sukharyuk D. (2007a). Outstanding universal value of the ecological processes in the primeval beech forests of the Carpathians and their management as World Heritage Sites. Bratislava: VEDA, vydavatel'stvo SAV.

Pichler, V., Vološčuk, I. \& Bublinec E. (2007b). Designation of corridors connecting primeval forests properties within the East Carpathian Biosphere Reserve (Slovak Part). In Z. Guziová (Ed.), Priorities for Conservation of Biodiversity in Biosphere Reserves in changing conditions (pp.121-126). Proceedings from the International Conference, Stará Lesná, Tatry Biosphere Reserve, Slovakia, 2-6 June. Bratislava: Slovak National Committee for UNESCO MAB Programme.

Plachter, H., Hoffmann, A., Panek, N. \& Schmidt P.A. (2008). European Beech forests as a Natural site on the World Heritage List of UNESCO. In H.D. Knapp (Ed.), Beech Forests - a German contribution to the global forest biodiversity. Bonn: Bundesampt für Naturschutz (BfN), Federal Agency for Nature Conservation. Skripten, 233, 53-60.

Sandwith, T., Shine, C., Hamilton, L. \& Sheppard D. (2001). Transboundary Protected Areas for Peace and Co-operation. Gland, Switzerland and Cambridge: IUCN.

Saniga, M. (2002). Structure, production conditions and regeneration processes of the beech virgin forest Rožok (in Slovak). Ochrana Prírody, 21, 207-218.

Saniga, M. (2003). Structure, production conditions and regeneration processes of the beech virgin forest Havešová (in Slovak). Ochrana Prírody, 22, 179-190.

Saniga, M. (2011): Primeval beech forests. In M. Barna, J. Kulfan \& E. Bublinec (Eds.), Buk a bukové ekosystémy Slovenska (pp. 209-226). Bratislava: VEDA, vydavatel'stvo SAV.

Saniga, M. \& Klimaš V. (2004). Structure, production conditions and regeneration processes of the beech virgin forest Stužica in 4. forest vegetation stage (in Slovak). Acta Facultatis Forestalia Zvolen, 46, 93-104.

Saniga, M. \& Schütz J.Ph. (2001). Dynamik das Totholzes in zwei gemischten Urväldern der Westkarpaten in pflanzengeographischen Bereich der Tannen-Buchen und der Buchenwälder in verschidenen Entwicklugsstadien. Schweitzerische Zeitschrift für Forstwesen, 152, 407-416.

Saniga, M. \& Schütz J.Ph. (2002). Relation of dead wood course within the development cycle of selected virgin forests in Slovakia. J. For. Sci. (Prague), 48, 513-528.

Saniga, M. \& Sklenár P. (2003). Structure, production and regeneration processes of the beech virgin forest in National Nature Reserve Oblík (in Slovak). Acta Facultatis Forestalis Zvolen, 45, 169-178. 
Stolton, S. \& Dudley N. (Eds.) (1999). Partnership for protection. London: Earthscan.

Stolton, S., Hockings, M., Dudley, N., Mackinnom, K. \& Written T. (2003). Reporting Progress in Protected Areas. A siteLevel Management Effectiveness Tracking Tool. Gland, Switzerland: World Bank Washington, USA/WWF Alliance for Forest Conservation and Sustainable Use.

Stolton, S., Dudley, N. \& Shadie P. (2012). Managing Natural World Heritage. Gland, Switzerland: UNESCO, ICCROM, ICOMOS, IUCN.

Stoyko, S., Sayik, D.S., Tatarinov, K.A., Tretyak, P.R., Tasenkevitsch, L.O., Malinovskij, K.A., Schewtschenko, S.V., Sukhariuk, D.D., Milkina, L.I., Komendar, V.I., Miller, M.P. \& Manyiko M.P. (1982). The Carpathian Reserve. Uzhgorod: Karpaty.

Stoyko, S. \& Tasenkevitch L. (1993). Some aspects of endemism in the Ukrainian Carpathians. Fragm. Florist. Geobot. Suppl., 2(1), 343-353.

Stoyko, S. (2002). The Virgin Ecosystems of Ukraine, their polyfunctional significance for nature protection (in Ukraine). L'viv: Naukovi Praci Lisivničoji Akademii Nauk Ukrainy.

Synge, H. (2004). European Models of Good Practice in Protected Areas. Gland, Switzerland and Cambridge, UK and the Austrian Federal Ministry of Agriculture, Forestry, Environment and Water Management: IUCN..

Thomas, L. \& Middleton J. (2003). Guidelines for Management Planning of Protected Areas. Gland, Switzerland and Cambridge: IUCN.

Turnock, D. (2002). Ecoregion-based conservation in the Carpathians and the land use implications. Land Use Policy, 19, 47-63. DOI: 10.1016/S0264-8377(01)00039-4.

Udvardy, M. (1975). A Classification of Biogeographical Provinces of the World. IUCN Occasional Paper No.18. Morges: IUCN.

Vološčuk, I. (1992). Biological diversity in the Carpathians. Oecol. Mont., 2, 43-47.

Vološčuk, I. (1994). Conservation and Rational Use of Forest ecosystems in Carpathian Mountains. In I. Vološčuk (Ed.), Research and Management of the Carpathian Natural and Primeval Forests (pp. 5-10). Ustrzyki Gorne: Bieszczady National Park, Association of the Carpathian National Parks and Protected Areas.

Vološčuk, I. (1995). Long-term Ecological Research and Monitoring on Carpathian National Parks and Biosphere Reserves. In F. Hamor \& I. Vološčuk (Eds.), Methods of monitoring of the nature in the Carpathian National Parks and Protected Areas (pp. 10-22). Rakhiv: Carpathian Biosphere Reserve, Association of the Carpathian National Parks and Protected Areas.

Vološčuk, I. (Ed.) (1999). The National Parks and Biosphere Reserves in Carpathians. The Last Nature Paradises. Tatranská Lomnica: ACANAP.

Vološčuk, I. (2003). The geobiocenological research in the natural forest ecosystems of the Carpathian protected areas. The Monographical Studies on National Parks 3. Tatranská Štrba: State Nature Conservancy, Tatry National Park Administration.

Wilshusen, P.R., Brechin, S.R., Fortwangler, C.L. \& West P.C. (2002). Reinvesting a Square Wheel: Critique of Resurgent „Protection Paradigm “in International Biodiversity Conservation. Society and Natural Resources, 15, 17-40. DOI: $10.1080 / 089419202317174002$.

Zbicz, D.C. \& Green M.J.B. (1997). Status of the world's transfrontier protected areas. Parks, 7(3), 5-10.

Zlatník, A. \& Hilitzer A. (1932). The Review of Nature Reserves and their proposals in Transcarpathian Ruthenia (in Czech). Sborník Masarykovy Akademie Práce, 6(2), 33-84.

Zlatník, A. (1934). The Study of the State Forests in Transcarpathian Ruthenia. First Volume. The Contribution to the history of state forests and forestry in Transcarpathian Ruthenia (in Czech). Sborník Výzkumných Ústavi̊ Zemědělských ČSR, sv. 126. Praha: Ministerstvo zemědělství republiky Československé,

Zlatník, A. (1935). The Study of the State Forests in Transcarpathian Ruthenia. Second Volume and Third Volume (in Czech). Sborník Výzkumných Ústavi̊ Zemědělských ČSR, sv. 127. Praha: Ministerstvo zemědělství republiky Československé.

Zlatník, A. (1936). Luzhanskyi Virgin Forest in Subcarpathian Ruthenia, the largest Czechoslovakian Firgin Forest (in Czech). Krása Našeho Domova, 28, 110-118.

Zlatník, A., Korsuň, F., Kočetov, F. \& Kseneman M. (1938). The Investigation of Natural Forests in Transcarpathian Ruthenia. First Volume (in Czech). Sborník Výskumných Ústavů Zemědělských ČSR, sv. 152. Brno: Ministerstvo zemědělství republiky Československé.

Zukrigl, K., Eckhardt, G. \& Nather J. (1963). Standortskundliche und waldbauliche Untersuchungen in Urwaldresten der niederösterreichischen Kalkalpen. Mitteilungen der forstlichen Bundesversuchsanstalt. 